\title{
Kentsel Yaşama Bilimsel, Görsel, Rekreasyonel Katkılar; Botanik Bahçeleri
}

\author{
Yasemin MÜMINOĞLU1 ${ }^{1} \&$, Bahar Türkyılmaz TAHTA ${ }^{1}$, Bahriye Gülgün ASLAN ${ }^{1}$ \\ ${ }^{1}$ Ege Üniversitesi Ziraat Fakültesi Peyzaj Mimarlığg Bölümü, İzmir, Türkiye \\ $\bowtie$ : kemaled@yahoo.com
}

Geliş (Received): 16.04.2018

Düzeltme (Revision):13.05.2018

Kabul (Accepted): 22.05.2018

\begin{abstract}
ÖZ
Yoğun teknolojik gelişmelerin baskısı altında kalan kentsel yaşam alanları, her geçen gün biraz daha yeşilini yitirmektedir. Yeşil alanlardaki bu kayboluş, beraberinde pek çok kaybı da getirmektedir. Oysaki şehirlerde yer alan yeşil alan sistemleri, faydaları itibariyle; insanların gelecekte sağlıklı bir yaşam sürmelerini sağlamada önemli bir yatırımdır. Bu sistemler; Doğal hayatı yaşatmada, mikroklima oluşturmada katkı sağlayıcı önemli bir unsurdur, her mevsim farklı doğa manzaraları sunarak insan psikolojisinde pozitif etki yaratan, rekreasyonel etkinlik yapılan alanlardır. Yeşil alanların önemini vurgulamak amacıyla hazırlanan bu çalışmada, Botanik Bahçeleri ele alınmıştır. Botanik bahçeleri; farklı doğa güzelliklerini bünyesinde barındırmakta, değişik iklimlerde yetişen birçok bitkinin insanlar tarafından tanınmasına aracılık etmektedir. Botanik bahçelerin içinde eğitim amacıyla çeşitli bitkilerin sergilendiği alanlar mevcuttur. Bu bahçeler, turistik amaçla da kullanıldıkları için bulundukları ülkelerin sosyoekonomik yapısını güçlendirmede etkili olabilmektedir.
\end{abstract}

Anahtar Kelimeler: Botanik Bahçesi, Peyzaj Planlama, Peyzaj Tasarım

Botanical Gardens: The Scientific, Visual And Recreational Contributions To Urban Life

\begin{abstract}
Urban living environments lose their state of greenness every other day, under the dense pressure of technological advancements. This disappearance in green areas accompanies many other losses. However, green space systems in cities are significant investments for citizens, given the fact that they help people have healthy lives in the future. These systems are important components to contribute to sustaining natural life and forming microclimate. In addition, they are recreational areas that bring positive effects on human psychology by offering different natural landscapes every season. This study aims to emphasize the importance of green areas within the sample of Botanical Gardens. Botanical gardens embody different natural beauties and help a variety of plants, indigenous to different climates, be introduced to people. There are specific areas in the botanical gardens that contain a diversity of plants exhibited for educational purposes. Furthermore, since these areas have a major function for the tourism industry, they are effective for strengthening the socio-economic structures of the given countries.
\end{abstract}

Keywords: Botanical Garden, Landscape Planning, Landscape Design

\section{GíRIŞ̧}

Çalışan insanların dinlenme şekillerinden en önemlilerinden biri; doğa ile içe içe geçirdikleri zamandır. Şehirde yaşayan insanlar için ise kent dokusu içindeki yeşil alanlardan başka doğaya yaklaşma imkânı yoktur. Günümüzde bu imkânsızlıklar, 'Uygarlık zararları' olarak bilinen çeşitli patolojik hastalıklara, örneğin hareketsizlikten doğan dolaşım bozuklukları ve kalp hastalıklarının ortaya çıkmasına neden olan en önemli faktörlerden biridir. Bu nedenle, şehirlerde yer alan yeşil alan sistemi, sağlayacağ insanların gelecekte sağlıklı bir yaşam sürmeleri için gerçek bir tıbbi yatırım niteliğini taşımaktadır [1].

Kentlerin büyümesi ve gelişmesi, otomatik olarak

Yasemin MÜMINOĞLU (D orcid.org/0000-0002-1574-2774 Bahar Türkyılmaz TAHTA orcid.org/0000-0003-2355-5714 Bahriye Gülgün ASLAN orcid.org/0000-0002-7071-8486 olağan boyutta doğal yeşil alanların azalması ve hatta yok olmasına yol açmaktadır. Sanayi'nin artması, yeni yol ve yaşam alanlarının yapımı, acımasızca doğal ortamın yok olmasına sebep olmaktadır [2].

[3]'a göre: "Dünyanın birçok ülkesinde rastlanan botanik bahçeleri, bu açıdan büyük bir önem taşımaktadır. İnsanlara canlı bitkilerle tanışma olanağını sunan botanik bahçeleri, canlı bitki örneklerinin sergilendiği, aynı zamanda herbaryum merkezlerinde kurutulmuş bitki örneklerini barındırabilen bahçelerdir. Turizm açısından da önemli bir yere sahip olan botanik bahçeleri, bulunduğu kente gelen turistlerin gezip görmek isteyecekleri önemli yerlerden birini oluşturmaktadır."

\section{MATERYAL ve METOD}

$\mathrm{Bu}$ çalışmanın materyalini çeşitli ülkelerde bulunan botanik bahçeleri oluşturmuştur. İncelenen botanik bahçelerinin kapladığı alan, yapısal ve yapısal 
olmayan elemanları, strüktürü ve işlevi, eğitsel, rekreatif ve turizm açısından önemi, bitki kolleksiyonları, herbaryum, seralar ve havuzların mevcudiyeti araştırılmıştır. İncelenen kaynaklara dayanarak botanik bahçelerinin tanımı, önemi [4-11], amaçları [4] ve işlevleri [12] ortaya konmuştur. Botanik bahçelerinin tarihine kısaca değinilerek ve dünyadan örnekler alınarak incelenmiş, mevcut durumları karşılaştırılmıştır. Botanik bahçelerinin büyüklük ve amaçlarına uygun olarak yer seçim kriterleri açıklanmıştır [12-14]. Ayrıca, botanik bahçelerinde bulunması gereken bölümler hakkında bilgi verilmiştir [12]. Elde edilen tüm araştırma kaynaklarına dayanılarak sonuç ve öneriler getirilmiştir.

\section{BOTANIK BAHÇELERİ TANIMI VE ÖNEMİ}

Uluslararası Botanik Bahçeleri Koruma Örgütü (BGCI) botanik bahçelerini; araştırma, koruma, sergileme ve eğitim amacıyla canlı bitki koleksiyonlarının yer aldığ kuruluşlar olarak nitelendirmektedir [4]. Bir diğer tanıma göre Botanik bahçeleri; yürüme yolları, oturma ve seyir alanları, su yüzeyleri, düzenlenmiş bitki koleksiyonları, kafeterya ve restoranları, hayvanat ve çocuk bahçeleri gibi farklı nitelikli birimleriyle çok yönlü pasif rekreasyon merkezleridir [5].

[6]'ya göre; botanik bahçeleri, dünyanın doğal ve kültür bitkilerini, amaçlarına uygun olarak, belirli bir düzen içinde yetiştiren, halka ve öğrencilere tanıtarak onları eğiten, bitki türleri üzerinde değişik amaçlı bilimsel araştırmalar yapan kuruluşlardır. Botanik bahçesi, bir rekreasyon alanı olması yanı sıra bir eğitim kuruluşudur. Bir yandan halkın rekreatif ihtiyaçlarına cevap verirken bir yandan da onlara botanik bilimi hakkında kısıtlı da olsa bazı bilgiler sunmaktadır. Botanik bahçeleri; barındırdıkları bitki kompozisyonları ile insanlara mevsimler boyunca farklı doğa manzaraları seyretme imkânı sunar. $\mathrm{Bu}$ farklı doğa güzellikleri, insanları günlük yaşamın stresinden arındırır ve insanların doğaya karşı pozitif tutum ve davranışlar sergilemesinde etkin rol alır. Yürüyüş yolları, seyir noktaları, kafeler, restoranlar, hediyelik eşya ve bitki satış alanları, botanik bahçelerinin rekreatif işlevleri içinde ele alınan yerlerdir. Botanik bahçelerinin kuruluş amaçları her ülkede benzer olsa da, kullanım biçimleri ve faydalanma, ülkenin ve yörenin sosyo-ekonomik yapısı, genel kültür durumuna göre farklılıklar gösterebilmektedir [7].

Kentlerde kurulan botanik bahçelerinin çoğunun hedefi, vatandaşları, özellikle de çocukları doğaya yaklaştırmaktır. Üniversite bahçelerinden farklı olarak bunlar daha çok halk için düşünüldügüunden, birçok bitkinin yanı sıra kuşhaneleri, akvaryumları ve küçük hayvanat bahçeleri, çocuklar için oyun alanları, kafeler ve bahçe restoranları vardır [15]. Büyük botanik bahçelerinin çoğunda teknik dergiler ve broşürler yayımlamak, ayrıca resimli kitap ve filmler hazırlamak önemli ve botanik bahçesinin tanıtımı için gereklidir [8].
Gerek kişisel gerekse toplumsal anlamda rekreasyonel gereksinimlerin karşılandığı tüm dış mekânların, bitkilerle iç içe düşünülmesi gerekir. Çünkü ortamın yeşillendirilmesi, oksijen miktarının artmasına, havanın temizlenmesine, mikro klimanın oluşmasına, gürültüden korumasına hatta psikolojik etkisi sonucu (rahatlama, deşarj olma) insan sağlığını direk etkileyerek pozitif etki yaratılmasına imkân sağlar [9]. Botanik bahçeleri; nesilleri tükenme tehlikesiyle yüz yüze olan bitki türlerini korumak, nesillerinin devamını sağlamak, bunun yanı sıra eğitim ve öğretimde yararlanmak ve bitki üzerinde bilimsel araştırmalarda bulunmak amaçlarıyla tesis edilen en önemli yerlerdir [4].

Bugünkü tahminlere göre dünyada var olduğu kabul edilen 270.000 bitki türünün yaklaşık \% 30’u ile Uluslararası Doğayı Koruma Birliği (International Union for Conservation of Nature) Kırmızı Listesi'ne göre; nesli tükenme tehlikesiyle karşı karşıya olan 10.000'den fazla bitki türünün üçte biri botanik bahçelerinde kültüre alınmıştır [10].

Botanik bahçelerinin önemi şu şekilde özetlenebilir [11]:

- Bilimsel açıdan; Birer laboratuvardır, müzedir, araştırmacıları bir araya getirir,

- Koruma açısından; Doğal ve kültürel varlıklar tahrip edilince koruma ihtiyacı doğmuştur,

- Prestij açısından; Gelişmiş ülkelerde şehir tanıtım broşürlerinde yer alır, doğa sevgisi aşılar, bilgilendirir tanıyarak korumaya yöneltir,

- Tarımsal ve ormancılık açısından önemlidir,

- Peyzaj mimarlığı çalışmaları açısından; canlı ve cansız donatılardan dolayı önemlidir,

- Rekreasyonel turizm açısından; tur programlarına alındığı için önemlidir,

- Kentsel diş mekân olarak önemi; bitki materyali çok ve açık mekân olduğundan önemlidir,

- Estetik güzellik açısından önemlidir,

- Mali açıdan; yatırılan para çeşitli etkinliklerle geri kazanılabilir,

- Çeşitli bitkileri bir arada görebilme olanağ açısından önemlidir,

- Yeşil alan olarak önemi; oksijen miktarına pozitif etkisi ve iklimi yumuşatması açısından önemlidir.

\subsection{Botanik Bahçelerinin Amaçları}

Botanik bahçeleri genel olarak şu amaçlar çerçevesinde fonksiyon göstermektedir;

- Botaniğin Modern Taksonomi ve alt dalları için bir laboratuvar görevi üstlenmesi,

- Dünyanın belirli bölgelerinde yetişen, ekonomik öneme sahip, adaptasyon değeri büyük; kahve, çay, vanilya, kauçuk, kakao gibi bazı bitki türleri için adaptasyon istasyonu görevini üstlenmesi,

- Bünyesinde hortikültürel yönden çalışmalar yapılması,

- Çevre baskısına maruz kalan, yok olma tehlikesi altında bulunan endemik ve nadir bitkilerin korunması, 
bu sayede doğa koruma alanlarının sürekliliğinin sağlanmasında da görev üstlenmiş olması,

- Sosyal ve kültürel anlamda en önemli amacı da; topluma bitkileri sevdirmek ve tanıtmaktır [4].

\subsection{Botanik Bahçelerinin İşlevleri}

Botanik bahçelerin koruma işlevi, bilimsel işlev, eğitim öğretim işlevi, doğa sevgisi oluşturma işlevi ve kurumsal işlevler (yayın yapar, kurslar ve sergi düzenler, hediyelik eşya üretirler) gibi çeşitli işlevleri vardır. En önemli işlevlerinin başında; çeşitli bitkileri özellikle nesli tükenme tehlikesi bulunanları saptamak, korumak ve çoğaltılmalarına katkıda bulunmak yer almaktadır. Botanik bahçelerinin Anabilim Dalı çerçevesinde çeşitli araştırmaların yapılmasına olanak sağlamaları yanında her yaştan insana bitkilerle ilgili bilgiler sunmak ve bu konudaki meraklarının giderilmesine yardımcı olmak gibi işlevleri, doğa sevgisi oluşturmaya büyük katkılar sunmaktadır. Ayrıca botanik bahçeleri, bir kurum olarak da eğitim toplantıları düzenlemek, yayım hizmetleri vermek, araştırıcıları bir araya getirmek, dokümanlar oluşturmak, sergiler düzenlemek gibi işlevlere de sahiptir [12].

\section{BOTANIK BAHÇELERININ TARIHSEL GELIŞìi}

Botanik bahçelerine, bugünkü anlamda olmasa da ilk çağlardan bu yana rastlamak olasıdır. Ancak bu bahçelerde amaç daha çok ekonomik ve tıbbi yararlar elde etmek olmuştur. $\mathrm{Bu}$ amaçla önceleri tapınak bahçelerinde, manastırlarda rahipler tarafından çeşitli türlerde bitkiler yetiştirilmiş, zaman zaman buralarda bitkiler üzerinde çeşitli araştırmalar yapılmıştır. Örneğin; bir din adamı olan Mendel, kendi ismiyle anılan ünlü yasasını bu tür mekânlarda bitkiler üzerinde yaptığı çalışmalar sonucunda ortaya koymuştur.

İlk botanik bahçesinin M.Ö. 350 yıllarında Atina'da Aristoteles tarafından oluşturulduğu birçok otorite tarafından kabul edilmekte idi. Eğitim amacıyla kurulan ilk botanik bahçesi 1545 yılında İtalya'nın Padua kentinde tesis edilmiştir (Şekil 1). Ancak aynı ülkenin Pisa kentindeki botanik bahçesinin bundan 2 yll önce planlandığı da iddialar arasındadır (Şekil 2). Paris’teki Jardin Botanigue 1610'da, Londra'daki Chelsea Physich Garden 1673'de tesis edilmişlerdir. Çok yönlü bir eğitim ve rekreasyon alanı olan botanik bahçelerine bugün sosyo-ekonomik bakımdan gelişmiş tüm ülkelerin küçük yerleşim alanlarında bile rastlamak mümkündür. 1987 yılı rakamlarına göre; Dünyada 125 ülkede 1457 botanik bahçesi bulunmaktadır. Bu bahçeleri her y1l 150.000.000' un üzerinde insan ziyaret etmektedir [16].

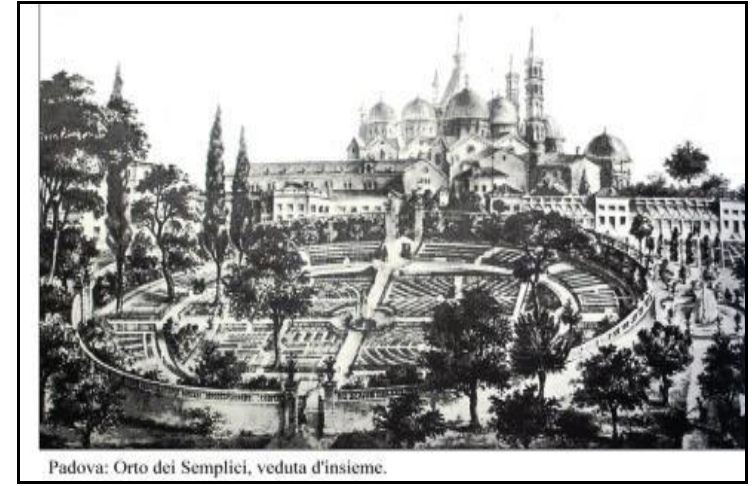

Şekil 1. Padua Botanik Bahçesi [17].

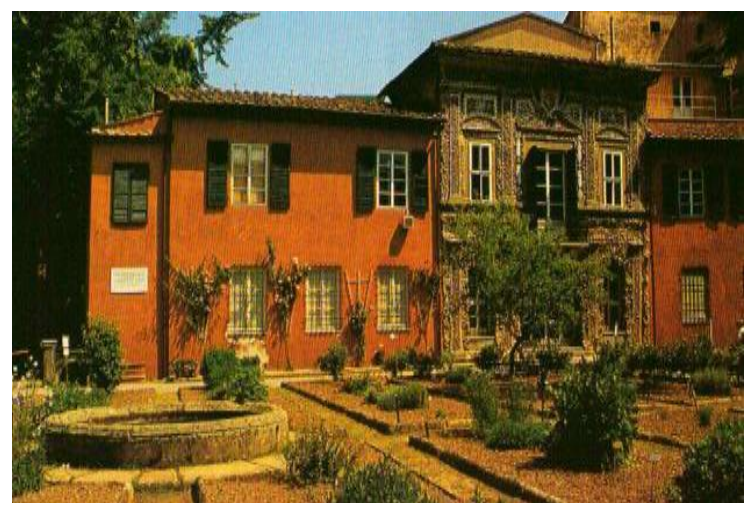

Şekil 2. Pisa Botanik Bahçesi [17].

\subsection{Dünyadan Botanik Bahçesi Örnekleri}

16. yy içinde sadece İtalya, Hollanda ve Almanya gibi ülkelerde bulunan, işlevleri ve kullanım olanakları açısından, kentsel diş mekânlar içinde özel bir yere sahip olan botanik bahçelerinin sayıları, sosyoekonomik gelişmelerini tamamlamış ülkelerde diğer ülkelere nazaran fazla artmıştır [10].

Botanik bahçeleri, alan büyüklügüü bakımından oldukça değişmektedir. Örneğin, Padua Botanik bahçesi çok küçük alana sahip olup bilimsel etkinliği fazladır. En geniş alana sahip $\left(120.000 \mathrm{~m}^{2}\right.$ arazi) botanik bahçelerinden biri olan Kew Gardens, hem eğitsel alanda hem de rekreatif bakımdan en fazla olanaklar sunan botanik bahçelerindendir. Bu botanik bahçesine benzer yapıda olanlar Edinburg, Hiroshima, Berlin ve Frankfurt bahçeleridir. Başta İngiltere ve İskoçya (Şekil 3) olmak üzere Singapur, Frankfurt ve Berlin botanik bahçeleri önemli miktarlarda dış turizme de açılmışlardır (18). 


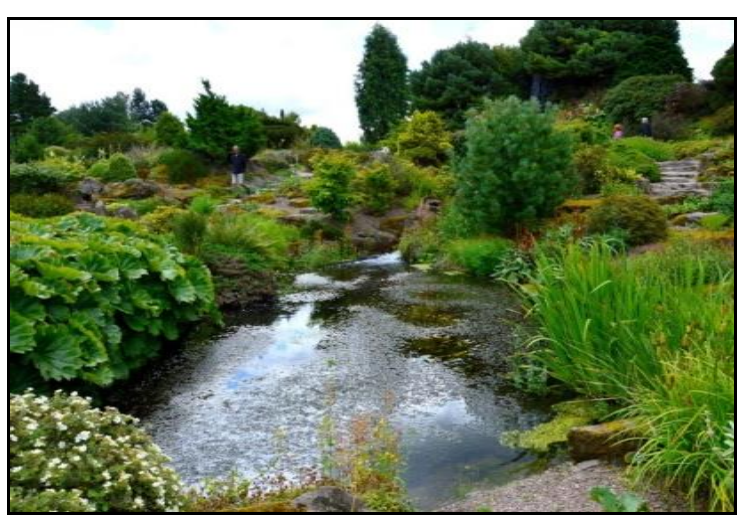

Şekil 3. Royal Botanik Bahçesi İskoçya [19].

Japonya'da ağırlıklı olarak başta eğitim kurumları olmak üzere tüm toplumun bilinçlendirilmesi için yoğunlaşmıştır. $280.000 \mathrm{~m}^{2}$ bir alan üzerinde kurulu Fransa'daki Paris Botanik Bahçesi, ünlü Seine Nehri'nin kıyısında olup içinde bulunan botanik okulunda öğrencilere bitki bakımı ve bahçe oluşturma sanatı öğretilmektedir (18). $140.000 \quad \mathrm{~m}^{2} \quad$ büyüklüğündeki İspanya Barcelona Botanik Bahçesinde dünyanın farklı bölgelerinden getirilmiş yüzlerce değişik bitki yetiştirilmektedir [20]. 1.000.000 $\mathrm{m}^{2}$ alana kurulu New York Botanik Bahçesi, Bronx (Şekil 4), aynı zamanda dünyanın en büyük bitki laboratuvarlarından birine sahiptir [21].

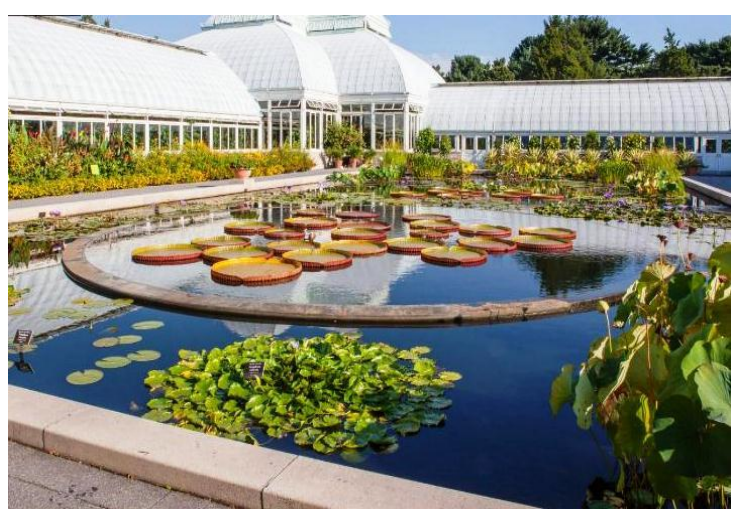

Şekil 4. New York Botanik Bahçesi, ABD [22].

11.000.000 $\mathrm{m}^{2}$ ' da kurulu Kraliyet Botanik Bahçesi, Kanada'nın en büyük botanik bahçesi olup, ülkenin başta gelen kültürel, eğitsel ve bilimsel kurumları arasında yer alarak turistleri çekmektedir [10]. On binden fazla bitki türüne ev sahipliği yapan Güney Afrika'daki Kirstenbosch Ulusal Botanik Bahçesi, aynı zamanda Afrika'nın ilk botanik bahçesidir. 11 farklı bölümden oluşan ve sulaması 3 nehirle sağlanan sistem sayesinde yapılan bahçe 2000'li yıllarda UNESCO tarafindan Dünya Mirası Listesine alınan tek milli botanik bahçesi olmuştur [23], Merkezi Beyaz Rusya'daki Botanik Bahçesi, 1967 yılında bilimaraştırma statüsü almıştır. Araştırma konuları; bitkilerin introdüksiyonu ve iklimleştirmesi, 'yeşil inşaat' ve mimarlıktır [24]. Özbekistan Taşkent Botanik Bahçesi Orta Asya'daki en büyük, (680.000 $\left.\mathrm{m}^{2}\right)$ alana sahiptir. Kapalı seralarda tropik ve subtropik bitkiler yetiştirilmektedir. Alanda bulunan 5 göl üzerinde nilüfer gibi sulak alan bitkileri sergilenmektedir [25]. Bakü Merkezi Botanik Bahçesi deniz seviyesinden 105- 135 $\mathrm{m}$ yüksekliktedir. Kütüphanesinde kendi akademik personelinin yazdığı kitap ve çalışmaları bulunmaktadır [26], Merdekan Dendrariumu, daha önceleri zengin birine aitken (Murtuza Muhtarov), $120.000 \mathrm{~m}^{2}$ arazi 1966 yılında Botanik Enstitüsüne geçmiştir [27]. Burada, 1800 kadar bitki türü, 28 tür hayvan ve ziyaretçilerin dinlenebilmeleri için çeşitli oturma ve gezme yerleri, eski köşk (şimdiki zamanda bilimsel çalışmaların yapıldığı yer), havuzlar ve üzerinde kayıkla gezebilme imkânı sunulmuştur [28].

\subsection{Türkiye’den Botanik Bahçesi Örnekleri}

Türkiye'de Botanik Bahçeleri ilk olarak Bizans ve Osmanlı İmparatorluğu dönemlerinde meyve, sebze ve özellikle de tıbbi bitkilerin yetiştirilmesi için yapılmıştır. Ancak modern anlamda ilk botanik bahçesi, bugünkü Galatasaray Lisesinin bulunduğu yerde kurulan "Mekteb-i Tıbbiye-i Şahane" binasının yanında, 1839 yılında hizmete açılan "Galata Sarayı Botanik Bahçesi” olmuştur [4].

İstanbul Üniversitesi Alfred Heilbronn Botanik Bahçesi 1935 yılında hizmete giren Türkiye'nin en eski botanik bahçesi unvanını almıştır. Öğrencilere ve öğretim üyelerine araştırma imkânı sunmakla birlikte halka açıktır. Eski, zengin içeriği ve İstanbul'da bulunduğundan dolayı turist akımına da uğramaktadır. Alanında; Seralar, Bitki Satış Yerleri, Tropik ve Subtropik Bitki Koleksiyonu, Dünya Bitkileri Koleksiyonu, Egzotik Bitkiler Koleksiyonu, Endemik Bitkiler Koleksiyonu, Herbaryum, Kütüphane, Yürüyüş Yolları, Havuzlar bulunmaktadır [29].

Türkiye'deki botanik bahçeleri genelde eğitsel ve rekreasyonel açıdan dünyadakilerden geridedirler. Ancak, $500.000 \mathrm{~m}^{2}$ büyüklügündeki Nezahat Gökyiğit Botanik bahçesi henüz yeni kurulmuş olmakla birlikte, eğitim ve sosyal etkinlikler konusunda kuruluşu 100 yılı geçen bazı botanik bahçelerine göre çok daha iyi durumdadır. Alanında; Herbaryum, Kütüphane, Havuz, Yürüyüş Yolları, Seyir Alanları, Piknik Alanları, Seralar, Çim Alanları, Kaya Bahçesi, Odunsu Bitki Koleksiyonu bulunmaktadır [7].

İzmir'de bulunan Ege Üniversitesi Botanik Bahçesi ve Herbaryum Merkezi, Ege Üniversitesi, Fen Fakültesi, Botanik Kürsüleri bünyesi içinde 1964 y1lında kurulmuştur. Ege Üniversitesi Kampüsü içinde 20.000 $\mathrm{m}^{2}$, lik bir alana sahiptir (Şekil 5, 6, 7, 8, 9, 10, 11). Bahçenin $1.300 \mathrm{~m}^{2}$ ' lik bir kısmında 2 adet araştırma, 9 adet öğretim tanıtım amaçlı olmak üzere 11 adet seras1 vardır. Üniversite bünyesinde olmasından dolayı öğrenci ve öğretim üyelerine araştırma imkânı sunmakla birlikte halka açıktır ve gerektiğinde rehber eşliğinde gezi düzenlenmektedir. Aynı zamanda orta öğretim 
öğrencilerine de tanıtım ve gezi yapılmaktadır. Alanında; Seralar, Bitki Satış Yeri, Odunsu Bitkiler Koleksiyonu, Gül Koleksiyonu, Kaya Bahçesi, Ekonomik ve Faydalı Bitkiler Koleksiyonu bulunmaktadir [30, 31].

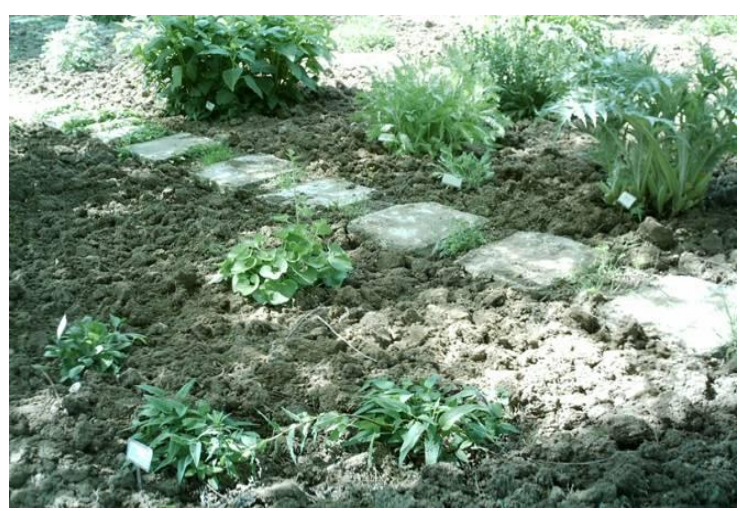

Şekil 5. Sistematik Bölüm, Ege Üniversitesi Botanik Bahçesi, İzmir (orijinal, 2006).

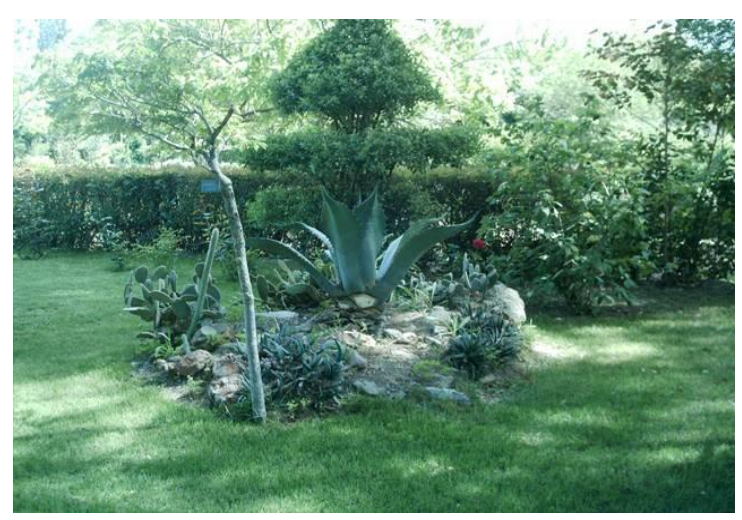

Şekil 6. Kaya Bahçesi, Ege Üniversitesi Botanik Bahçesi, İzmir (orijinal, 2006).

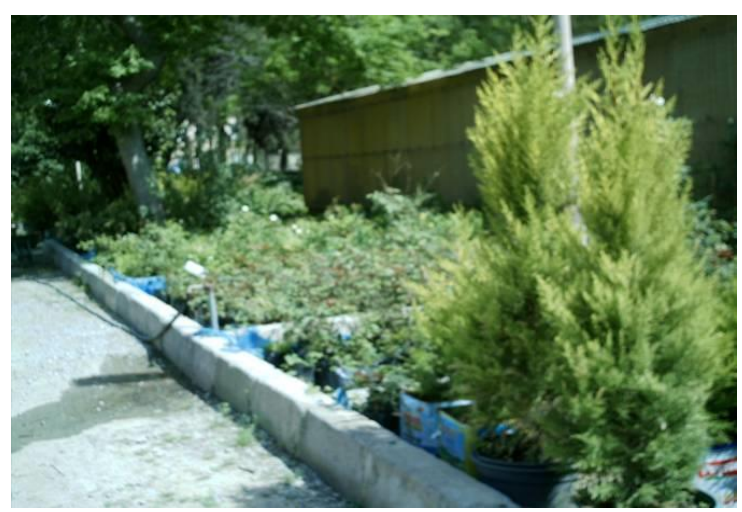

Şekil 7. Bitki Satış Yeri, Ege Üniversitesi Botanik Bahçesi, İzmir (orijinal, 2006).

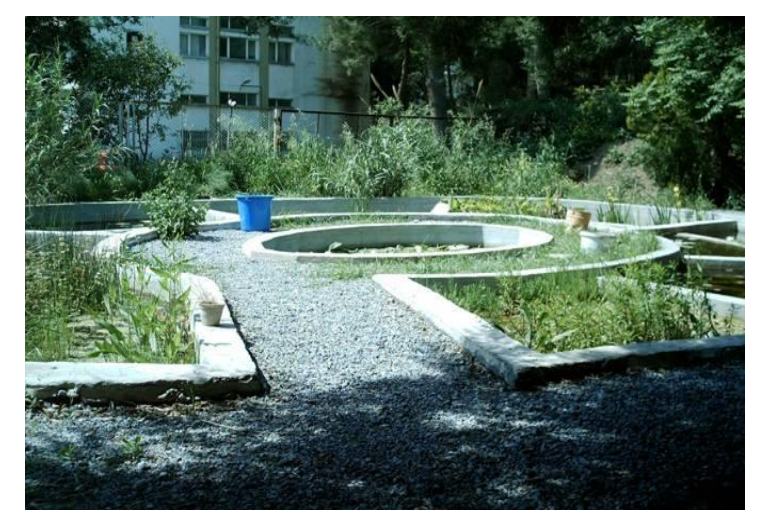

Şekil 8. Havuz, Ege Üniversitesi Botanik Bahçesi, İzmir (orijinal, 2006).

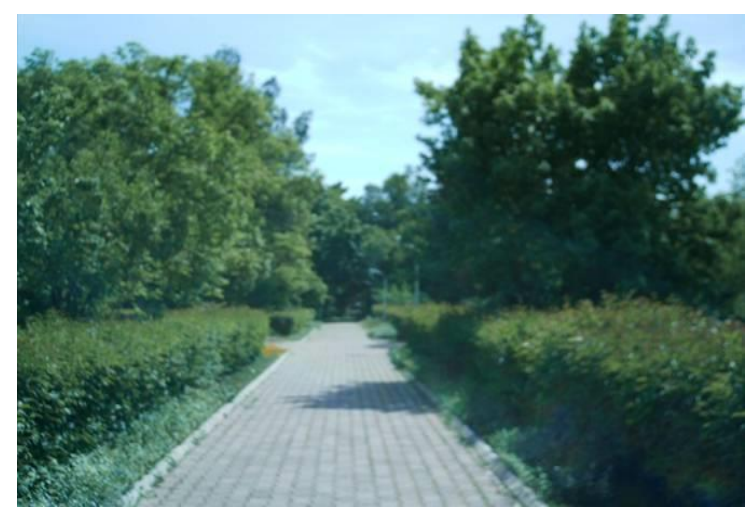

Şekil 9. Arboretum, Ege Üniversitesi Botanik Bahçesi, İzmir (orijinal, 2006).

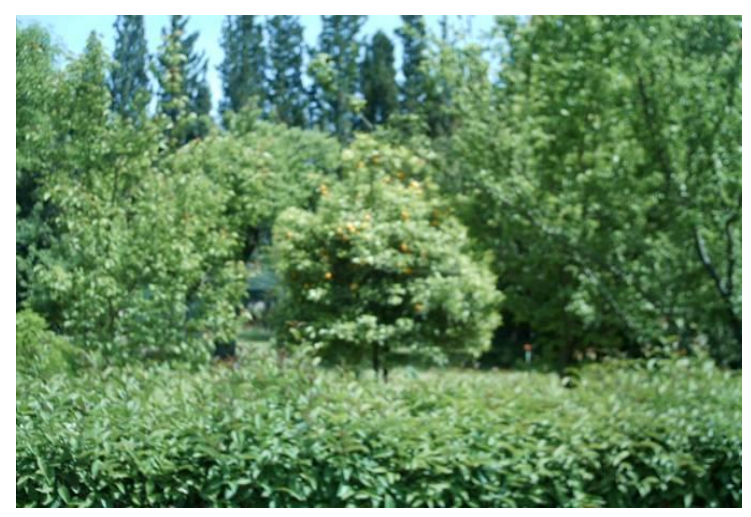

Şekil 10. Meyve Bahçesi, Ege Üniversitesi Botanik Bahçesi, İzmir (orijinal, 2006). 


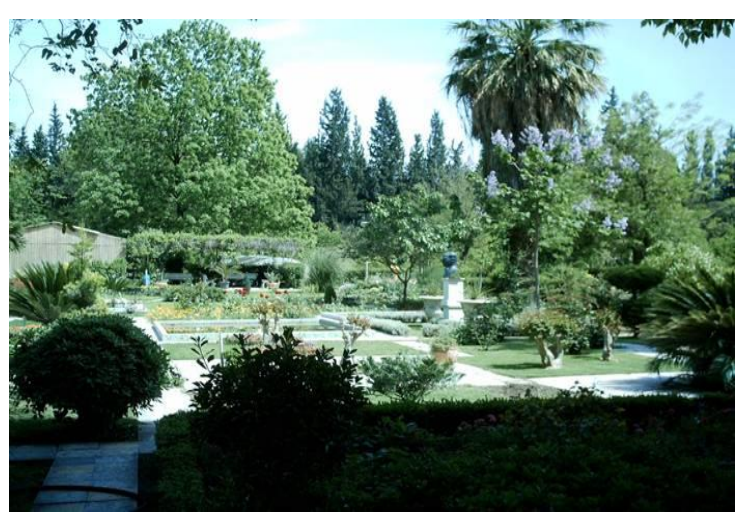

Şekil 11. Giriş, Ege Üniversitesi Botanik Bahçesi, İzmir (orijinal, 2006).

$350.000 \mathrm{~m}^{2}$ büyüklüğündeki Ata Botanik Bahçesi (Şekil 12), deniz seviyesinden 1850 m yüksekteki Erzurum kent merkezinde olup Atatürk Üniversitesi arazisinde bulunmaktadır. Alanında; Gölet, Ahşap Hizmet Binası, Pergola ve Kamelyalar, Oturma Alanları, Amfitiyatro, Otopark, Köprü, Kaya Bahçeleri, Koşu Alanları, Yürüyüş Yolları, Hayvanların Sergilendiği Alan, Sera, Bitki Satış Yerleri, Meyve Bahçesi, Çim Alanlar, Çiçek Gösteri Alanları, Ağaç ve Çalı Koleksiyonu bulunmaktadır [3].

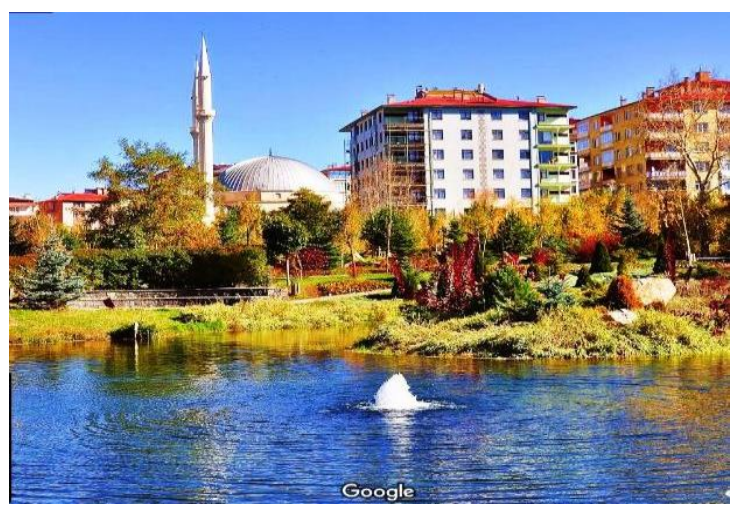

Şekil 12. Ata Botanik Bahçesi, Erzurum [32].

Karaca Arboretum, Türkiye'nin ilk özel arboretumlarından biridir (Şekil 13). Öncelikli amaçları arasında, dünyadaki ağaç ve odunsu bitki türlerine, şartlar elverdiğince barınak oluşturmak, bunların varlığını sürdürmesi için uğraş vermek, bir gen merkezi gibi çalışarak bunların üremesine ve uygun şartlarda yayılmasına olanak sağlamaktır. Alanında; Yürüyüş Yolları, Havuzlar, Ev, Meyve Bahçeleri, Odunsu Bitkiler Koleksiyonları, Dünya Bitkileri Koleksiyonu bulunmaktadır [33].

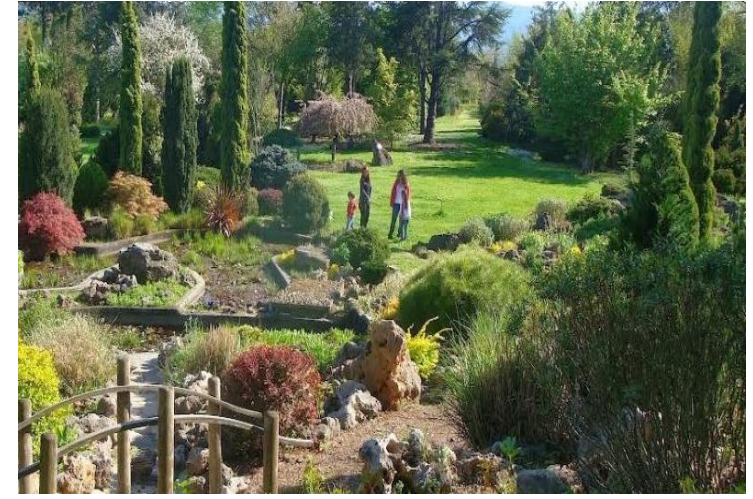

Şekil 13. Karaca Arboretum, Yalova [34].

Türkiye botanik bahçeleri genelde üniversite dahilinde faaliyet gösterdiklerinden bilimsel çalışmalara daha çok üstünlük vermektedirler. Bunun yanında rekreatif yönü de düşünülerek ziyaretçilere ya bazı günler ya da tüm günler açıktırlar. Bazı botanik bahçelerinde canlı bitki yada hediyelik eşya satın almak da mümkündür.

Aşağıda verilen tabloda (Tablo 1), araştırmada incelenen dünya botanik bahçelerinin yapısal ve yapısal olmayan bölümleri karşılaştırılmıştır.

Tablo 1. Dünya Botanik Bahçelerinin Karşılaştırılması (orijinal, 2018).

\begin{tabular}{|c|c|c|c|c|c|c|c|c|c|c|c|}
\hline Botanik BahcesiAd1 & 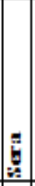 & 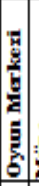 & & & 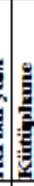 & 焉 & 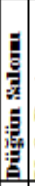 & 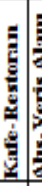 & & & 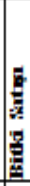 \\
\hline Kew Gardens & + & + & + & & & & & & & & \\
\hline Royal Botanik Bahçesi, Ed inburgh & + & & & + & + & & & & & & \\
\hline Paris Botanik Bahçesi, Fransa & + & & + & & & + & & & & & \\
\hline Zürh Botanik Bahçesi, Isviçre & + & & & + & + & & + & + & & & \\
\hline Barcelona Botanik Bahcesti. Ispansa & + & & & + & + & & & + & & & \\
\hline Stutgart: Wilhalma Botanik Bahçesi, Almanya & + & & & + & + & + & + & ++ & & & \\
\hline New York Botanik Bahresi, Bronx, ABD & + & & & & & & & & + & + & \\
\hline Kraliyet Botanik Bahçesi, Burlington, Kan ad a & + & & & & & + & & & & + & \\
\hline Kirstentbosch Ulusal Botanik: Bahcesi, G. Afrika & + & & & & & + & & & & & \\
\hline Avustralya Ulusal Botanik Bahçesi, Canberra & + & & & & & + & & + & & & \\
\hline Kyoto Botarik Bahcesi, Japonya & + & & & + & + & & + & ++ & & & + \\
\hline Singapur Botarik Bahçeai, Singapur & + & & & + & + & & + & ++ & + & + & + \\
\hline Şangay Botanik Bahçesi, Çin & + & & & + & + & & + & + & + & & + \\
\hline Vilnivs Botanik Bahçesi & + & & + & + & + & & & & & + & 4 \\
\hline Merkezi Bolanik Bahçe, Beyaz Rusya & + & & & & & & & & & + & \\
\hline Lomonosov Botanik Bahçesi_Moskova & + & & & & + & & & & & & + \\
\hline Grigla adira Milli Botanik: Bahcessi,Ukraysa & + & & & & & & & & & + & \\
\hline Trgskent Botanik Bahçesi & + & & & & & & & & & + & \\
\hline Kazakistan Botanik Bahçesi & + & & & & & & & & + & & \\
\hline Merkezi Bolanik Bahçe, Bakü & + & & & + & ++ & & & & & & \\
\hline Merdekan Dendrariumy & + & & & & ++ & & & + & & + & + \\
\hline Alfred Heilbronn Botarik Bahcesi & + & & & & ++ & & & & & + & + \\
\hline Nezahat Gökyiğit Botanik Bahcesi & + & & & & ++ & & & & & + & \\
\hline Ege Üniversites Botanik Bahçesi & + & & & & ++ & & & & & + & + \\
\hline Ata Botarik Bahçesi & + & & + & + & & + & & & & + & + \\
\hline Karaca Arboretum & & & & & & & & & & + & \\
\hline
\end{tabular}


Tabloya dayanarak, dünya botanik bahçelerinde hangi yapılara öncelik verildiği açıkça görülmektedir. Bunların; seralar, herbaryum, kütüphane, havuz ve bitki satış yerleri olduğunu söylenebilir.

\section{BOTANIKK BAHÇESI YER SEÇIM KRITTERLERİ}

Botanik bahçesi tesis edilirken öncelikle hangi amaca ya da amaçlara hizmet edeceği araştırılmalıdır. Her yer için ideal bir planlama ve uygun bir kullanış olanağı aramak mümkün olduğu gibi, her kullanma ihtiyacına uygun bir yer bulmak da mümkündür. Herhangi bir amaç için planciya teklif edilen bir yerde, her şeyden evvel, o yerin önerilen amaca ve kullanışa uygun olup olmadığ belirlenmelidir. Aksi takdirde, böyle bir planlamanın bünyesini teşkil eden üniteler ve bütün mekân, olumsuz yönde etkilenebilir [13]. Botanik bahçesi planlanırken önemli noktalardan biri de, planının ve tasarımın yeterince esnek olması ve gerektiğinde başka bir alana uygulanabilmesidir. Ayrıca, seçilen yerin boyutları da önemlidir. Örneğin; uluslararası öneme sahip botanik bahçelerinin 500.000-1.000.000 $\mathrm{m}^{2}$, ulusal botanik bahçelerinin 300.000-500.000 $\mathrm{m}^{2}$, bölgesel botanik bahçelerinin 250.000-50.000 $\mathrm{m}^{2}$, üniversiteye bağlı sadece eğitsel amaçlı botanik bahçelerinin ise 50.000$100.000 \mathrm{~m}^{2}$ olması tavsiye edilir. Botanik bahçesi alanını planlanan bölümlere ayırarak, örneğin; meyve bahçesi, deneysel bahçe, 1slah bitkileri bölümü, yerel bitkiler, endemik bitkiler, kültür bitkiler, sistematik bitkiler bölümü, seyir alanı, dinlenme alanı gibi yeterli alan sağlamak da önemlidir [14].

Botanik bahçeleri büyüklüklerine göre; bitki koleksiyonları, seralar, idari yapı, laboratuvar, teknik donanım alanı gibi bölümler içerdiğinden ve aynı zamanda eğitsel ve araştırmacı yönünden dolayı diğer parklardan ayrılmaktadır. $\mathrm{Bu}$ nedenle de botanik bahçesine ayrılacak yerin özenle seçilmesi gerekir. Bunun için ekolojik koşullar, ulaşım, sulama olanakları gibi unsurlar önem kazanmaktadır [14]. Botanik bahçesinin işlevlerini yerine getirebilmesi için seçilecek yer ile ilgili olarak; Meteorolojik durum, Topraktopoğrafya, Su, Bitki örtüsü, Sosyo-kültürel ve sosyoekonomik yapı gibi verilerin elde edilmesi ve kararların bunlara göre verilmesi önemlidir [12].

\subsection{Botanik Bahçesi Bölümleri}

\subsubsection{Yapısal bölümler:}

Botanik bahçesinde yönetim için, bitkiler açısından uygun yetişme ortamlarının sağlanması için eğitimöğretim ve araştırma ile bahçede çalışan ve ziyaretçilerin çeşitli gereksinmelerini karşılamak için, bahçe işlevlerini tamamlayıcı bazı yapısal ögelerin olması gerekmektedir. Bunlar [12]:

Yönetim merkezi: Botanik bahçesiyle ilgili her türlü işlerin planlanıp programlanacağı, araştırma, eğitimöğretim faaliyetlerinin sürdürüleceği, misafirlerin kabul edileceği, bahçe yönetici ve sorumluların aktivitelerini gerçekleştirecekleri merkezi binadır. Bir ya da birkaç katlı olarak bahçenin uygun bir bölümünde tesis edilir. İçerisinde bahçe yöneticisi ve diğer sorumlular için çalışma odaları, bürolar, toplantı salonu, laboratuvar, kütüphane, misafirhane ile dinlenme salonu, duş, tuvalet vb. bölümler bulunmaktadır.

Herbaryum: Herbaryumda tüm bitki türlerini bir arada ve çok daha küçük bir alanda toplamak ve teşhir etmek olasıdır. Botanik bahçesi canlı bitkiler sergisi olmasına karşın, herbaryum cansız bitkiler müzesidir. Bu yüzden dünyanın neresinden toplanmış olursa olsun tüm bitkileri aynı yerde korumaya almak olasıdır. Bir herbaryum; bitki aramada kolaylık sağlamak için sistematik bir şekilde düzenlenmiş, kurutulmuş preslenmiş ve özel kâğıtlara yapıştırılarak üzerine gerekli bilgileri kaydedilmiş bitkilerden oluşan bir koleksiyondur. Çekmeceli rafları olan özel kasalarda muhafaza edilir. Kasalar toz geçirmez ve böceklere karşı muhafazalı olmalıdır. Herbaryum, yönetim binası içinde yer alabilir.

Bahçe personeli için gerekli sosyal tesisler: Zorunlu gereksinmelere cevap verecek niteliktedir. Soyunma odaları, duş, tuvalet, dinlenme yeri vb. bölümlerdir. Ayrı bir bina olabileceği gibi yönetim merkeziyle birlikte tek bir bina olarak da tesis edilebilir.

Depolar: Bahçede kullanılan, saksı, gübre, tohum, ilaç vb. gibi ekipmanların ve aletlerin konulabileceği yerdir. Bunların kapalı mekânlar olması tercih sebebidir.

Fümigasyon odası: Dışarıdan getirilen tohum ve diğer bitkisel materyalin herhangi bir hastalık ve zararlı taşımasına karşın önlem olarak önce karantinaya alınıp, her türlü hastalık ve zararlılardan arındırılması işlemlerinin yapıldığı odadır.

Teknik servis: Bahçe içerisinde çeşitli binaların ve seraların 1sıtılması için bir merkezi 1sıtma sistemine gereksinim vardır. Bu sistemin çevreye toz duman ve özellikle bitkiler için $\mathrm{SO}_{2}$ vb. gazlar çıkarmaması bitkilerin sağlığı için yararlı olur. Elektrik, çeşitli alet ve ekipmanların çalışması, aydınlatma, soğutma vb. işlerde gereklidir. En önemli ve temel gereksinim sudur. En ekonomik çözüm, bahçenin kendi suyunu bulmasıdır.

Seralar: Amaçlarına göre üç tip sera bulunmaktadır. Bunlar:

- Demonstrasyon seraları, (yükseklikleri fazla, ziyaretçilere açık seralardır),

- Üretim seraları, (deneme araştırma seraları dahil, ziyaretçilere açık olmayan, yoğun çalışma gerçekleştirilen seralardır),

- Deneme- araştırma seralarıdır.

Camekânlı yastıklar: Üretim amacıyla kullanılırlar, 1sitmalı ve 1sitmasiz tesis edilirler. Kismen ya da tamamen toprağa gömülü bir durum gösterirler.

Havuz, derecik ve göletler: Su bitkileri için gerekli olduğu kadar, bahçe içinde estetik bir görünüm sağlama görevleri de vardır. Bunlar yapay olarak yapılabildiği 
gibi mevcut bir dere veya gölet, bu amaçla kullanılabilir.

Gölge Elemanları: Sarılıcı ve tırmanıcı bitkilere uygun yetişme ortamı sağlamak için tesis edilen elemanlardır.

Yol ve otoparklar: Ziyaretçilerin her yeri gezebilmeleri için yolların tasarımına ayrı bir özen gösterilmelidir. Ayrıca yeterli sayıda otopark alanı tesis edilmelidir.

Rüzgâr perdeleri ve sınırlama elemanları: Bahçeyi hâkim rüzgârlara karşı korumak için canlı-cansız rüzgâr perdelerine ve yine bahçeyi sınırlamak ve dışarıdan gelecek zararlı etkilere karşı bahçeyi korumak amacıyla bahçe duvarına gereksinim duyulur.

Ziyaretçilere yönelik tesis ve olanakları: Rekreasyonel kullanımların önem kazanmasıyla birlikte botanik bahçelerinde ziyaretçilere yönelik tesisler gelişme göstermektedir. Örneğin: restoran, kafe ve çay evi, çocuk oyun alanları gibi.

\subsubsection{Yapısal olmayan bölümler:}

Botanik bahçesinde bulunması gereken yapısal olmayan bölümler şöyle sıralanabilir: arboretum, ekonomik bitkiler bölümü, bitki sistematiği bölümü, bitki morfolojisi bölümü, bitki ekolojisi bölümü, bitkilerde evolüsyon ve islah bölümü, coğrafik bölgeler bölümü, süs bitkileri ve bahçe düzenleme bölümleri gibi. Bunlar aşağıdaki gibi açıklanabilir [12]:

Arboretum Odunsu bitkilerin (ağaç, ağaççık, çalıların) bilimsel ve eğitsel amaçlarla kültürlerinin yapıldığ alandır. Önemli özelliği, tüm bitkilerin genel adıyla, bilimsel adını ve kaynağını içeren bir etiketle uygun şekilde etiketlenmiş olmasıdır. Burada bitkiler, doğal yaşamlarına benzer bir şekilde yetiştirilir ve bitkilerin düzenlenmesi çoğunlukla familyalarına göre yapılır. Bazıları ise bitkilerin yetişme ekolojilerine göre, diğerleri ise türlerin coğrafik kaynaklarına uygun olarak düzenlenir. $\mathrm{Bu}$ nedenle dünyanın değişik bölgelerini temsil eden bitkilerin minyatür manzaralarını doğal haliyle görmek olasıdır. Ayrıca bitkilerin ekonomik veya estetik yönlerine uygun olarak da düzenlemeler yapilabilir.

Ekonomik bitkiler bölümü: Kendilerinden ekonomik yarar sağlanan bitkiler yararlanma şekli ya da yararlanılan kısımlarına göre sinıflandırılarak ayrı parseller oluşturulur. Örneğin: meyveli bitkiler, tahıllar, yumru ve köklerinde yararlanılan bitkiler, baharatlı bitkiler, tıbbi bitkiler vb.

Bitki sistematiği bölümü: Bitkiler takım ya da familya itibariyle ve belirli bir sisteme uygun olarak gruplar halinde yerleştirilir. Yerleştirme sistemi ya alfabetik düzende yapılır ya da çeşitli araştırıcıların geliştirmiş oldukları sistemlere göre yapılır.

Bitki morfolojisi bölümü: Bitkiler kendi aralarında kök, gövde, yaprak, meyve, tohum yapıları yönünden büyük farklılıklar göstermektedir. Bunlara dayanarak bitkileri belirli morfolojik gruplara ayırmak mümkündür (örneğin, yaprak şekillerine göre vb.).

Bitki ekolojisi bölümü: Bataklık, su, kurakçıl, alpin gibi farklı ekolojik mekân birimi bitkilerinin yer aldıkları bölümdür. Bitkilerin bu tür bölümlerde yer alabilmelerine yardımcı olmak amacıyla yapay göller, bataklıklar, havuzlar, kaya bahçeleri oluşturulur. $\mathrm{Bu}$ bölüm açıkta ve seralar içinde yer alabilir.

Bitkilerde evolüsyon ve ıslah bölümü: Burada bitkiler üzerinde çeşitli araştırmalar (varyasyon, kalıtım, doğal ve yapay seleksiyon, melezleme, mutasyon) yapılır ve bu konularla ilgili koleksiyonlara yer verilir.

Coğrafi bölgeler bölümü: Değişik coğrafi bölgelerin bitkilerinden örneklerin verildiği bir bölümdür. Örneğin; tropik bitkiler, subtropik bitkiler gibi.

Süs bitkileri ve bahçe düzenleme bölümü: Gerek gösteri gerekse üretim amacıyla çeşitli süs bitkilerinin yerleştikleri bölümdür. Bu bölümde Çin bahçesi, Japon bahçesi vb. özel bahçe tipleriyle; pergolalar, havuzlar, kaya bahçeleri gibi bahçe bölümleri örnekleri de yer almaktadır.

\section{SONUÇ VE ÖNERILER}

Modern Kentlerde doğal yapının azalması ve bozulması nedeniyle insan için rahatlayabileceği tabii mekânları yaratma ihtiyacı gün geçtikçe artmaktadır. Botanik bahçelerinin oluşturulması, yaşatılması ve halka açık olması, insanların doğa ile iç içe olmasını sağlamakla birlikte onların çeşitli bitkiler hakkında bilgi edinebileceği kültürünü yükseltebileceği yeşil alanlardır. Özellikle üniversitelere bağlı olduklarında öğrenciler ve akademik personel için araştırma ve bilgilenme alanı olarak görev yapmaktadırlar. Örneğin, araştırma ve yetiştirme seralarında farklı iklimlerden getirilen bitkileri görerek yaşama ve çoğalma şartları hakkında bilgi edinilebilir. Ayrıca öğrencilere ve halka yönelik çeşitli seminerlerin düzenlenmesi ile doğa sevgisini aşılamak mümkündür. Bunun için kuruluş amacına yönelik düzenlemelerin yapılması önemlidir. Örneğin; halka açık botanik bahçelerinde rekreasyon alanlarının (kafe, çocuk parkı, düğün salonu gibi), olması gerekir. Böyle alanların yapılması, botanik bahçelerine olan ilgiyi artırmakta ayrıca bahçede satılabilen hediyelik eşyalar ya da canlı bitkiler, bahçeye maddi katkı sağlamaktadır.

Botanik bahçeleri, ziyaretçilerine, Dünya'nın değişik bölgelerinde yetişen bitkilerin yanı sıra, kendi yörelerinin doğal bitki örtüsünü tanıtma misyonuna sahiptir olduğundan bitkiler hakkında bilgiler sunarak, bitki yaşamının zenginliklerinin tanıtılması ile çevre duyarlılığı ve koruma bilincinin oluşmasına da katk1 sağlamalıdır. Aynı zamanda, çeşitli eğitim toplantıları düzenleyerek, kurumsal yayınlar ve dokümanlar oluşturarak sahip oldukları pasif rekreasyon olanaklarının yanı sira, toplumun aktif rekreasyon gereksinimlerine de cevap vermeleri beklenir. Botanik bahçelerindeki rekreasyonel kullanımlar, ziyaretçilerin 
ailece bir günlerini dolu dolu bahçede geçirmelerini sağlayacak ve kullanıcılar üzerinde tekrar bu alana gelmelerine neden olacak izlenimler birakacak ve yıl boyunca farklılıklar gösterecek şekilde organize edilmeleri gerekmektedir [10].

Botanik bahçeleri son derece özel düzenlemeler ve planlamalar gerektirirler. Amacına uygun olarak planlanıp düzenlenmelidirler. Her bitkinin her ortamda ve toprakta yetiştirilemeyeceği düşünüldüğünde özel ortamların oluşturulması botanik bahçeleri için önemlidir. Örneğin, taşlık yerlerde yetişen bitkiler için kaya bahçeleri oluşturulup oraya uygun bitkiler yetiştirilmelidir, su bitkileri için havuz ya da göletler oluşturulmalıdır. Ayrıca seralar kurularak nemli ve kurak ortamları seven bitkiler yetiştirilmeye çalışılabilir. Toprak seçimi ve 1şık ihtiyacı bitki yetiştirmek için çok önemlidir. Örneğin, kumlu toprak isteyen bitkiler için kumluk yerler hazırlanmalıdır. Özel bitki gruplarına göre seralar hazırlanarak onlara uygun bir ortam oluşturulur. Palmiye çeşitlerinin, çöl bitkilerinin ve eğreltilerin, soğanl1-yumrulu bitkilerin, bulunduğu özel seralar hazırlanmalı. Her bitki için etiketler hazırlanarak, bu etiketlerde bitkinin yerel adı, Latince adı ve anavatanının hangi ülke olduğu belirtilmelidir. Bazı botanik bahçelerinde özel bitkiler için koleksiyonlar oluşturularak bir bitkinin dünya üzerinde bulunan bütün türlerini bir arada görme imkânı sunmaktadır. Bunun yanı sıra süs bitkilerinin birçok türünün sergileneceği yerler de yapılabilir. 'Rose Garden' adı verilen gül bahçeleri bunun en güzel örneklerinden biridir [8].

Botanik bahçeleri amacına uygun olarak planlarken ulaşıma, alan büyüklüğüne, ekolojik şartlara, sulama imkanına önem verilmelidir. Çünkü ziyaretçilere açık olan botanik bahçelerinde eğer ulaşım sıkıntısı var ise yeterince ziyaretçi gelemeyebilir dolayısıyla örneğin; kafe, restoran, düğün salonu gibi rekreasyona yönelik alanlardan beklenen performans alınamaz. Aynı zamanda botanik bahçesine girişler ücretli ise ve maddi olarak bahçenin idaresi buna bağlı ise az gelen ziyaretçi ile yeterince katkı sağlanamaz ve botanik bahçesinin yaşatılması güç olur.

Botanik bahçeleri planlanırken estetik güzelliğe önem verilirse, bahçe güzel park ve rahatlatıcı rekreasyon mekânı görünümü kazanabilir. Buna örnek olarak Dünya botanik bahçelerinden Kew Botanik Bahçesi verilebilir. Kew hem önemli bilimsel araştırmalar yapılan bir eğitim alanı hem de ünlü bir rekreasyon alanıdir.

Botanik bahçesi oluşturulurken, bitki ekolojisi ve sosyolojisine uygun olarak ada ve parsellere ayrilır. Planlama elde edilen verilere göre yapılır. İyi bir yol sirkülasyonu hazırlanır. Yol boyunca bitkiler familya, cins, tür, varyete ve kültür formlarına göre takdim edilir. Bitkilerin yakından incelenmesi için küçük doğal yollar ve taş basamaklar inşa edilebilir. Ağaç, ağaççık ve çalı grupları ile büyük mekânlar, çiçek ve otsu bitkilerle engin görünüşlü alanlar kurulabilir. Önlerine Latince ve Türkçe isimleri yazılı olduğu etiketler bulundurulmalıdır. Ana yollarda yer yer oturma ve dinlenme alanları, tepe ve yamaçlarda bakış terasları inşa edilebilir [35].

Farklı ekolojik şartlarda yetişen çeşitli bitki türlerinin sergilenebileceği seraların, botanik bahçelerinde önemli yeri vardır. Seralarda yetiştirilen bitki türleri için özel ekolojik şartlar oluşturulmaktadır. Bahçelerde yerleştirilen bilgilendirme panoları ve tabelalar ziyaretçilere bitkiler hakkında bilgi vermektedir.

Bazı botanik bahçeleri aralarında tohum alışverişi yapmakla, genetik bankın oluşturulmasına katk1 sağlamaktadır. Aynı zamanda farklı ekolojik şartlarda yetişen bitkilerin yeni ortamda yetiştirilmesi ve çoğaltılması çalışmalarına da imkân sağlamış olurlar.

Ulusal kullanım amacını dikkate alacak olursak; iklim, rüzgâr, topoğrafya gibi yerin doğal yapısı önemlidir. Uluslararası kullanım amacına uygun ise; sosyal, kültürel, politik açı önemli olur. Örneğin, Ankara'da Botanik Bahçesi ve Üniversitelerin Botanik Bölümlerine bağlı ise yeri ona yakın olmalı. Kamu arazisinde yapılan botanik bahçesi için daha az para ödenir. Ulaşımın kolay olması için yolun işlevsel olması önemlidir [11].

Botanik bahçeleri amaçlarına uygun olarak hizmet verirken, çalışacakları konuları da belirlemektedirler. Örneğin, Beyaz Rusya'da botanik bahçelerinin çalışması, araştırma konularına yönelmiştir. Bazı botanik bahçeleri şifalı bitkilerin araştırılmasına ve yetiştirilmesine, bazıları ise endemik ve yok olma tehlikesinde olan bitki türlerinin korunmasına ve çoğaltılmasına önem vermişlerdir.

Türkiye'de bulunan botanik bahçelerinde daha çok endemik ve nadir bitkilerin yetiştirilmesine ve çoğaltılmasına önem verilmiştir. Bunun yanında çeşitli bilimsel araştırmaların yürütülmesiyle birlikte ziyaretçilere yönelik bilgilendirme seminerleri, rehberli geziler, broşürlerin verilmesi gibi hizmetler de verilmektedir. Ayrıca bazı botanik bahçelerinde canlı çiçek satışı da mevcuttur.

Dolayısıyla, botanik bahçelerinde bilimsel çalışmaların yanında ziyaretçilere yönelik rekreasyon ortamının yaratılması, bahçeye gelir kaynağı sağlayacağı gibi, bağlı olduğu kuruluşa, hatta tüm ülkeye tanınma ve saygınlık değerini artırma olanağı vermektedir.

Botanik bahçesinin uygulanacağ grubuna hizmet edebilecek aktif ve pasif rekreasyon etkinliklerinin yanında yeterli otopark, kış aylarında da kullanım olanakları ile üniversite gençliği, yaşlılar, özürlüler gibi çeşitli kullanıcı gruplar dikkate alınmalıdır. Mekânın büyük bölümünün gün boyu etkin kullanımını sağlamak için bakım, yönetim ve güvenlik gibi çalışmaların program uyarınca yürütülmesi önemlidir. Alanın tasarımında başlıca program elemanları; çok amaçlı oyun ve spor alanı, su ögeleri ve sistemi, kafeterya gibi alanlar bulunması tavsiye edilir. Alanın topoğrafik yapısına hareket kazandırma yolunda farklı kotlarda mekânlar oluşturulmalıdır. Bu sayede elde edilecek kazı-dolgu malzemesi ile yapay tepeler ve seyir platformları oluşturulabilir [35]. 


\section{KAYNAKÇA}

[1] Sabaz M., Türkiye'de Kent Gelişimi ve Açikalan Gereksinimi, Doktora Tezi, Münih Teknik Üniversitesi, 1986.

[2] İvahova L.İ., Fesük S.S. Samoylov V.S., Modern Yeryüzü Tasarımı. İzdatelstvo 'Adelant', Arhangelsk, p. 3842009.

[3] Ata Botanik Bahçesi, www. atauni. edu. tr. /sayfa=atabotanik-bahcesi (Erişim tarihi: 8 Ekim-2014).

[4] Bakü Botanik Bahçesi. http://www.aznabatat.com/ru/index.htm, (Erişim tarihi: 18 Ekim 2014).

[5] Uzun G. Çukurova Üniversitesi Botanik Bahçesi Peyzaj Planlama İlkelerinin Saptanması Üzerine Bir Araştırma, (Basılmamıș Doçentlik Tezi), Ç.Ü. Fen Bilimleri Enstitüsü, Adana, 1978.

[6] Heywood V.H., The Changing Role of the Botanic Garden, IUCN Conservation Monitoring Centre, Kew, UK. 1987.

[7] Var M., Karaşah B., Botanik Bahçelerinin Kullanıcılara Sağladığı Eğitsel ve Rekreatif İmkânlar, III. Ulusal Karadeniz Ormanc1lık Kongresi, IV, 14671477, 2010.

[8] Sel F., Botanik Bahçesi Nedir Nasıl Hazırlanır, www.merakname.com/botanik-bahcesi-nedir-nasilhazirlanir. 2009, (Erişim tarihi: 14 Ekim 2014).

[9] Mamedov T.S., Bioekologiçeskiye Osobennosti Sennıh Derevyev i Kustarnikov Merdekanskogo Dendrariya i İh Znaçeniye v Ozelenenii Abşerona, Botanika İnstitutu, RUPS Matbaası, Bakü, 1-30 1999.

[10] Hepcan Ç, Özkan B. Botanik Bahçelerinin Kentsel Dış Mekânlar Olarak Kullanıcılara Sunduğu Olanakların Belirlenmesi, E.Ü. Ziraat. Fak. Derg., 42:3,159-170, 2005.

[11] Özkan B. Botanik Bahçelerin Planlanması, Ders notları, 2005.

[12] Özkan B., Kentsel Rekreasyon Alan Planlaması, E. Ü. Ziraat Fak. Peyzaj Mimarlığı Bölümü, Bornova- İzmir, 15:18, 38- 50, 2001.

[13] Aran S. Peyzaj Mimarisi Temel Prensipler, Ankara Üniversitesi Basımevi, Ankara, 1977.

[14] Sokolov M.P., Botaniçeskiye Sadı Osnova İh Ustroystva i Planirovka, İzdatelstvo Akademii Nauk SSSR, Moskova, 53-68, 1959.

[15] Sarkowicz H. Bahçelerin ve Parkların Tarihi, Dost Kitabevi Yayınları, Ankara, 276, 2003.

[16] Bramwell D. Botanic Garden and the World Conservation Strategy, Academic Press Inc. Ltd. London, 1987.

[17] Önder S., Konaklı N. Konya'da Botanik Bahçesi Planlama İlkelerinin Belirlenmesi, Tekirdağ Ziraat Fak. Dergisi 8:2, 2011.

[18] İstanbul B.B. www. istanbulforkids.com/konubasliklari/2014/2123/2123/ (Erişim tarihi: 20 Kasım 2014).

[19] İskoçya Royal Botanic Garden. Edinburgh, www.panoramio.com/photo. (Erişim tarihi: 14 Mayis2015).

[20] Barselona www.kendingez.com/barselona, (Erişim tarihi: 10 Kasım-2017).
[21] Bronx Dünyanın En Ünlü Botanik Bahçeleri. www.fwmail.net/genel-kultur/dunyanin-en-unlubotanik-bahceleri. (Erişim tarihi: 6 Kasım 2014).

[22] ABD Bronx New York Botanik Bahçesi. www.getyourguide.com.tr/new-york-159/, (Erişim tarihi: 10 Kasım-2017).

[23] Güney Afrika. www.ekonomi.dunyabulteni.net. (Erişim tarihi: 10 Kasım-2017).

[24] Merdekan Dendrari. www.science.gov.az/ru/merdekan/index.htm. (Erişim tarihi: 14 Ekim 2014).

[25] Central Asia Travel, Botanik Bahçe, www.centralasiatravel.com/ru/countries/uzbekistan/pl aces/tashkent/botanic_garden. (Erişim tarihi: 13 Kasım 2014).

[26] Demircan N., Yılmaz H. Erzurum Kentinde Botanik Bahçesi Oluşturulması Üzerine Bir Araştırma, Atatürk Üniv. Ziraat Fak. Derg. 35:3-4, 193-200, 2004.

[27] Tezis Rol Botaniçeskih Sadov v Ekologiçeskom Vospitanii Obşestva. Mejrespublikanskoye Soveşaniye V, 3-5 sentebre 1986, Riga, p. 5-9 1986.

[28] Lonely, Blog Merdekan. 2013, www.m.alo.az/blog/view_blog.php?id=996, (Erişim tarihi: 8 Ekim- 2014).

[29] Fransa. Dünya mirasları, http://www.gezialemi.com/DunyaMiraslariAyrinti.asp ?ID=120\&SAYFA=15. (Erişim tarihi: 28 Haziran 2006).

[30] Ege Üniversitesi Botanik Bahçesi. www.google.com.tr/maps/uv?hl=tr\&pb. (Erişim tarihi: 10 Kasim-2017).

[31] Ege Üniversitesi Botanik Bahçesi. www.google.com.tr/search?q=ege+botanik+bahçesi. (Erişim tarihi: 23 Kasım 2014).

[32] Ata Botanik Bahçesi, Erzurum www.google.com.tr/maps/uv (Erişim tarihi: 10 Kasım2017).

[33] Karaca Arboretum, www.karacaarboretum.com. (Erişim tarihi: 9 Kasım 2014).

[34] Karaca Arboretum. Yalova www.google.com.tr/search?q=Karaca+Arboretum, + Y alovadcr. (Erişim tarihi: 10 Kasım-2017).

[35] Tanrıverdi F. Peyzaj Mimarlığı Bahçe Sanatının Temel İlkeleri ve Uygulama Metodları, Atatürk Üniversitesi Basımevi, Erzurum, 1987. 